\title{
Spatial Analysis of Safety Factors due to Rain Infiltration in the Buyan-Beratan Ancient Mountains
}

\author{
I. Nengah Sinarta ${ }^{1}$, Ahmad Rifa'i $^{2}$, Teuku Faisal Fathani ${ }^{2}$, Wahyu Wilopo ${ }^{3}$
}

\begin{abstract}
Sukasada and Sawan Subdistricts are areas in Buleleng Regency that are often hit by landslides due to their geological conditions, since they are composed of weathered volcanic rocks, consisting of intersections with faults and rock joints. A rainfall model analysis is carried out in order to determine the probability of precipitation, while WindRose is used to analyze the duration of the dominant rainfall. Furthermore, SoilVision is used to determine the grain size distribution. Meanwhile, the equations proposed by van Genuchten and Fredlund and Xing are used to estimate the Soil-Water Characteristic Curve (SWCC). The Green-Ampt model is also used to calculate infiltration capacity. Slope stability is analyzed using an infinite slope model in order to produce a spatial-temporal prediction map of slope stability in the form of safety factor (SF). The results of the hydrology analysis reveal that rain with an intensity of 87.32-92.27 mm/day, a duration of 6-7 days, and types of soil in each study location in Sukasada and Sawan Subdistricts affects the amount of infiltration and it, in turn, affects slope stability. Extrapolation results for the spatial-temporal map of landslide hazard reveal the classification of safety factor as follows, SF > 2.13 (low/stable), $1.40<S F<2.12$ (moderate/critical) and $S F<1.39$ (high/landslide). Copyright (C) 2020 Praise Worthy Prize S.r.l. - All rights reserved.
\end{abstract}

Keywords: Spatial Analysis, Infinite Slope Stability, Infiltration, Rain Intensity, Safety Factor

\section{Nomenclature}

F $\quad$ Cumulative infiltration

$k_{\text {sat }} \quad$ Saturated coefficient permeability

$\beta \quad$ Angle of slope surface

$\psi \quad$ Matric suction head

$\Delta \theta \quad$ Volumetric water content difference

$z \quad$ Depth

$\theta_{i} \quad$ Initial water content

$\theta_{s} \quad$ Saturated water content

$h_{o} \quad$ Depth of ponding

$S_{e} \quad$ Air-entry value

$n_{e} \quad$ Porosity effective

$f(t) \quad$ Infiltration rate

$i \quad$ Intensity

$t \quad$ Time

$t_{p} \quad$ Ponding time

$F_{p} \quad$ Cumulative infiltration after ponding

SF Safety factor

$c^{\prime} \quad$ Soil cohesion

$\gamma_{t} \quad$ Saturated unit weight

$h \quad$ Total height

$u_{w} \quad$ Pore water pressure

$u_{a} \quad$ Pore air pressure

$\phi^{b} \quad$ Internal friction angle with matric suction

$\sigma_{n} \quad$ Normal stress

$\phi^{\prime} \quad$ Effective internal friction

$\tau_{n} \quad$ Shear stress

$F(t) \quad$ Cumulative infiltration

$\begin{array}{ll}L, z_{w} & \text { Depth of the wetting front } \\ \eta & \text { Porosity } \\ Z_{w} *(t) & \text { Time function of the depth of wetting front } \\ F & \text { Shear force } \\ W & \text { Weight of soil } \\ N & \text { Normal force }\end{array}$

\section{Introduction}

The hazard map of the soil movement from the research results has become the basis of the concept of early warning system for people who are vulnerable to landslides [1]. The Buyan-Beratan mountain range is a part of the Buleleng Regency, with hilly topography and geological condition originated from weathered volcanic rocks that have many faults. This area is an ancient caldera, which becomes a lake like Beratan Lake, Buyan Lake, and Tamblingan Lake due to changes in land use, resulting in frequent landslides [2]. According to the Bali Province BPBD report, land movements in the form of landslides or floods usually occur in the rainy season, especially in November-April, due to high rainfall with a percentage of occurrences of $17.21 \%$ of the safety factor of landslides in Bali [3]. It is also important to note that this condition tends to increase. The causes of the landslide in the area include slope inclination, rock conditions, slope constituents, rainfall, water system of slope, seismicity, and vegetation [4]. The composition of the rocks belongs to the group of Buyan-Beratan ancient 
volcanic rocks (Qpbb), which consists of tuffs and deposits of Buyan-Beratan and Batur volcanic lava which are of the upper quarter, based on landscape sightings and geological condition illustrated on Bali's geological map [5]. The composition of the rocks that includes volcanic deposits and weathering of volcanic rocks consisting of faults and joints can cause landslide in the caldera, and the infiltration of rain which increases the saturation degree of the soil and the weight of the slope itself can also cause landslide [6], [7]. The interpretation and use of the factors that cause soil movement, especially the natural or physical aspects, are important in order to conduct the proper research in creating hazard maps, and infiltration is also important because it is one of the causes of the soil movement due to its effect on the amount of water absorbed into the soil due to rainfall intensity. The mechanical parameters that should be introduced in the geotechnical calculations are often poorly known [8]. The research on the effect of rainfall on slope stability has become a topic of intensive research in the world [9]. Several empirical approaches have been used to determine the vulnerability level of landslide due to the impact of the intensity and duration of rainfall [10]. Slope stability analysis on finite slope in rainy season with timber crib wall can increase the safety factor > 1.5 [11]. Nevertheless, difficulties can be still found in measuring the amount of rainfall infiltration that can affect spatial slope stability. Rainwater infiltration modeling on spatial conditions uses seepage model from SEEP/W in order to obtain information on pore pressure required for slope stability analysis in each catchment model [12], [13]. Research on those factors needs to be carried out based on the analysis of hydrology and geological interpretation of ancient volcanic rocks where infiltration acts as a trigger for landslides, in order to obtain the safety factor based on the intensity of rainfall that is observed in spatial analysis. The ancient mountainous Buyan-Beratan has soil layer from weathering volcanic rocks consisting of sand, silt and volcanic breccia. During the rainy season, the area has always suffered landslides that threaten transportation infrastructure and residential areas; therefore, it is necessary to conduct a research on spasial slope stability due to infiltration.

\section{Theory and Literature}

\section{II.1. Infiltration Analysis}

One of the causes of landslides is rain. There are two types of rain: heavy rain and normal rain. Heavy rain is rain with an intensity of $70 \mathrm{~mm} /$ hour or more than 10 $\mathrm{mm}$ /day while normal rain is rain that lasts long with an intensity of less than $20 \mathrm{~mm} /$ day, and both types are a common cause of landslides in Indonesia [14]. The amount of the design rainfall in a certain return period is estimated using frequency analysis and statistic approach.

The types and intensity of rainfall in Indonesia can be seen in Table I [15].
TABLE I

RAINFALL CONDITIONS AND RAINFALL INTENSITY

\begin{tabular}{lcc}
\hline \hline \multicolumn{1}{c}{ Condition of rainfall } & \multicolumn{2}{c}{ Rainfall intensity $(\mathrm{mm})$} \\
& 1 hour & 24 hour \\
\hline Very light rain & $<1$ & $<5$ \\
Light rain & $1-5$ & $5-20$ \\
Normal rain & $5-20$ & $20-50$ \\
Heavy rain & $10-20$ & $50-100$ \\
Very heavy rain & $>20$ & $>100$ \\
\hline \hline
\end{tabular}

\section{II.2. Infiltration}

Infiltration capacity is the maximum capacity of water that can enter the soil [16]. If the infiltration of the water into the slope occurs continuously within a sufficient period and amount, it will push the soil and trigger a landslide. Long duration rain will increase the moisture content, while negative pore water pressure, cohesion, and internal friction angle decrease. Increased soil water level due to rain will reduce soil suction and increase soil weight [17]. The probability of slope failure is related to the accumulation of rainfall. The probability of slope failure is lower at the beginning of the rainy season and becomes higher at the end of the season [18], [19].

Therefore, in modeling, safety factor is a function of the depth of the wetting front associated with cumulative infiltration.

The Green-Ampt equation is one of several methods developed in order to calculate infiltration capacity. Infiltration equations are done by developing a more physical, theoretical approach in order to obtain exact analytical solutions.

The Green-Ampt approach uses the term wetting front, which is found at the depth $(L)$ reached at the time $(t)$ as in Fig. 1 [16]. The Green-Ampt infiltration model has been developed to model infiltration at horizontal soil surfaces. Modification is required for a certain angle of slope surface. The following is an infiltration equation at an inclined surface $(\beta)$ which requires modification. The following equation is an infiltration equation at inclined surface [20]. Cumulative infiltration is calculated using Equation (1):

$$
F=\left(k_{\text {sat }} \cos \beta\right) t+\frac{\psi \Delta \theta}{\cos \beta} \ln \left(1+\frac{F \cos \beta}{\psi \Delta \theta}\right)
$$

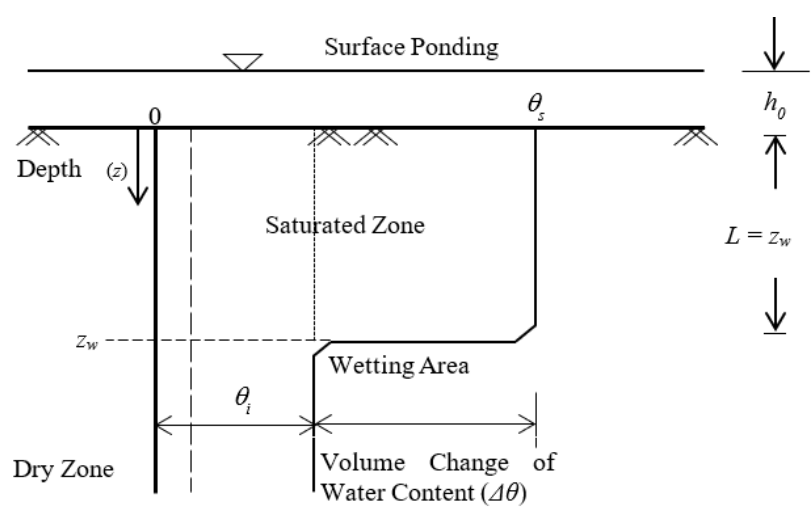

Fig. 1. Green-Ampt infiltration method 
Meanwhile, infiltration rate can be calculated using Equation (2) and Equation (3):

$$
\begin{gathered}
\Delta \theta=\left(1-S_{e}\right) n_{e} \\
f(t)=k_{\text {sat }}\left(\cos \beta+\frac{\psi \Delta \theta}{F}\right)
\end{gathered}
$$

$F$ is cumulative infiltration, $f(t)$ is infiltration rate, $\psi$ is matric suction head, $k_{s a t}$ is saturated soil permeability coefficient. Ponding time $\left(t_{p}\right)$ is the time needed by the land to reach saturated conditions $(S r=100 \%)$. The ponding time for the Green-Ampt equation uses Equation (4) and Equation (5):

$$
\begin{gathered}
i=k_{s a t}\left(\cos \beta+\frac{\psi \Delta \theta}{i t_{p}}\right) \\
t_{p}=\frac{k_{s a t} \psi \Delta \theta}{i\left(i-k_{s a t} \cos \beta\right)}
\end{gathered}
$$

The amount of the cumulative infiltration based on ponding time can be calculated using Equations (6)-(9):

$$
\begin{gathered}
t<t p: F=I \\
t=t p: F=F p \\
t>t p \\
F=k_{s a t}\left(t-t_{p}\right)+F_{p}+\frac{\psi \Delta \theta}{\cos \beta} \ln \left(\frac{\psi \Delta \theta+F \cos \beta}{\psi \Delta \theta+F_{p} \cos \beta}\right)
\end{gathered}
$$

\section{II.3. Infinite Slope}

Planar failure of the infinite slope model has been adjusted in the shallow slides analysis. Since the analysis is carried out on unsaturated soil, the safety factor of infinite slopes is measured based on the Mohr-Coulomb criteria [21]:

$$
S F=\left[\frac{c^{\prime}+\left(\sigma_{n}-u_{a}\right) \tan \phi^{\prime}+\left(u_{a}-u_{w}\right) \tan \phi^{b}}{\tau_{n}}\right]
$$

Modification of Equations (10) for conditions on infinite slope models assumes that the depth of hard soil or impermeable rock is very deep so that the collapse field is considered to occur in the wetting area as seen in Fig. 2. The modification to the equation is seen in Equation (11) [22]:

$$
S F=\frac{c^{\prime}+\left(\gamma_{t} h \cos ^{2} \beta-u_{w}\right) \tan \phi^{b}}{\gamma_{t} h \cos ^{2} \beta \tan \beta}
$$

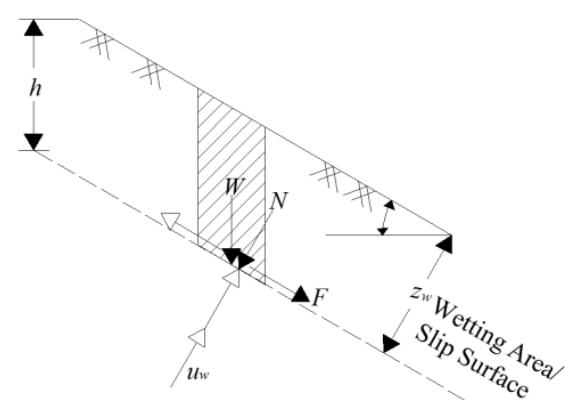

Fig. 2. Infinite slope model where the depth of hard soil is very deep

The depth of the wetting field $\left(z_{w}\right)$ is calculated based on the relation in Equation (12):

$$
F(t)=L\left(\eta-\theta_{i}\right)=z_{w} \Delta \theta
$$

For rain intensity that changes with time $(t)$, the depth of the wetting field is in Equation (13):

$$
z_{w} *(t)=\frac{F(t)}{\Delta \theta}
$$

\section{Research Methods}

The properties of soil, which are a technical parameter in the analysis of infiltration and soil stability, are obtained from tests carried out in the laboratory. Besides the test results, this research has also used literature interpretation of sample testing in Buleleng, with sampling points in Sukasada Subdistrict (Pancasari Village and Gitgit Village) and Sawan Subdistrict (Lemukih Village and Sekumpul Village).

Soil sampling is as shown in Fig. 3, with several

\begin{tabular}{|c|c|c|c|c|c|}
\hline \multirow{2}{*}{ Parameter } & \multicolumn{4}{|c|}{ "Research Location } & \multirow{2}{*}{ Unit } \\
\hline & Pancasari & Gitgit & Lemukih & Sekumpul & \\
\hline Type of Soil & $\mathrm{OH}$ & $M L$ & $M H$ & $M L$ & - \\
\hline $\begin{array}{l}\text { Dry volume } \\
\text { weight }\left(\gamma_{d}\right)\end{array}$ & 1.14 & 1.17 & 1.15 & 1.19 & $\mathrm{gr} / \mathrm{cm}^{3}$ \\
\hline Spesific grafity & 2.58 & 2.63 & 2.61 & 2.63 & - \\
\hline Soil Permeability & $2.10 \times 10^{-06}$ & $2.15 \times 10^{-06}$ & $2.51 \times 10^{-1}$ & ${ }^{6} 2.56 \times 10^{-06}$ & $\mathrm{~cm} / \mathrm{s}$ \\
\hline $\begin{array}{l}\text { Shear strength: } \\
\text { Cohesion }(c)\end{array}$ & 4.29 & 3.21 & 3.80 & 3.17 & $\mathrm{kPa}$ \\
\hline $\begin{array}{l}\text { Internal friction } \\
\qquad(\varphi)\end{array}$ & 35.12 & 34.56 & 30.32 & 33.63 & $\circ$ \\
\hline & 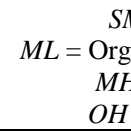 & $\begin{array}{l}I=\text { Silty sa } \\
\text { anic silt an } \\
=\text { Organic } \\
=\text { Organic }\end{array}$ & $\begin{array}{l}\text { nd } \\
\text { fine sand } \\
\text { silt } \\
\text { Clay }\end{array}$ & & \\
\hline
\end{tabular}
sample points in the surrounding area.

Table II shows that the soil in Sukasada and Sawan Subdistricts has a specific gravity value between 2.582.63 , and according to the Unified classification system, with a dry volume weight between $1.14-1.19 \mathrm{gr} / \mathrm{cm}^{3}$, the soil belongs to the group of organic clay $(\mathrm{OH})$ with $L L$ liquid limit > 50\%. Soil properties in Bongancina Village, Pempatan Village, and Munduk Village are used as comparison.

TABLE II

SOIL PROPERTIES INVESTIGATION 


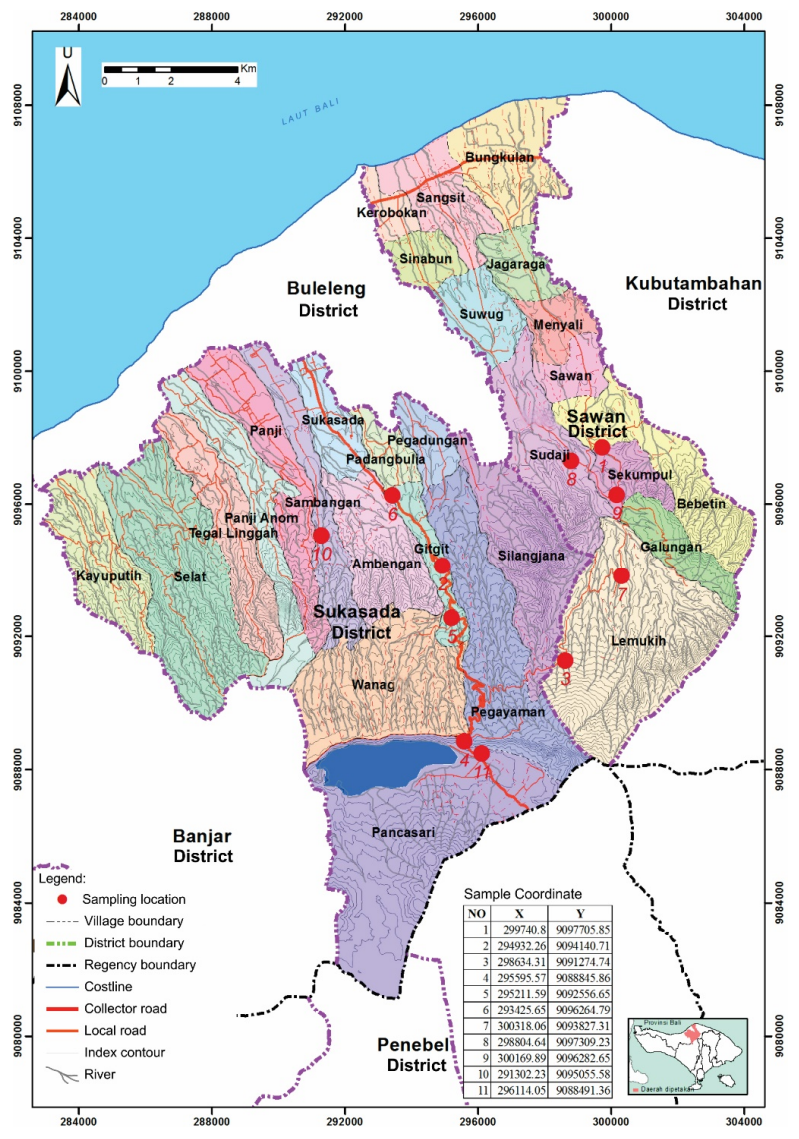

Fig. 3. Sampling Locations

This research also uses geological maps and Landsat 7-ETM satellite imagery in order to see the surface profile of Buleleng Regency in general. Rainfall data are collected from seven stations closest to the two subdistricts, namely the Bongancina, Gitgit, Munduk, Pedawa, Pempatan, Sawan, and Umadesa rain stations. Additionally, the data of the daily rainfall from 19932016 have been used to estimate rainfall intensity in Sawan and Sukasada Subdistricts. After collecting the data, the analysis of the rainfall infiltration is conducted.

A hazard map is created by converting the Earth's DEM (Digital Elevation Model) and slope data. For spatial processing, it is necessary to utilize digital data of land use obtained from satellite image processing using the Maximum Likelihood method. This research uses the band combination of 542 .

\section{Results and Discussion}

\section{IV.1. Infiltration Analysis}

Infiltration analysis begins with analyzing dominant rainfall using the WRPLOT View (Wind Rose Plots for Meteorological Data) in order to find out the distribution of the dominant rainfall duration in one month in each study location, which is analyzed in the form of a RainRose graph. In this research, daily rainfall data is used as input. Therefore, the dominant rainfall distribution can be obtained from the analysis of each rainfall station. The value of the dominant rainfall duration for each study location can be seen in Table III.

This table reveals a different dominant duration of rainfall for normal rain, heavy rain, and very heavy rain.

The rain with normal intensity has a longer duration compared to the one with very heavy intensity. The intensity of the design rainfall is analyzed using design rainfall with a 2-year return period.

The value of the rainfall obtained from the analysis is considered as a rain model representing the conditions in the field, in which rain occurs for 6 periods in 1 year from November to April.

The value of rainfall intensity for each study location is in Table IV.

The analysis of the infiltration capacity on slopes using the modified Green-Ampt equation shows that the soil with a saturation degree of $70 \%$ has a greater value of infiltration capacity than the one with a saturation degree of $80 \%, 90 \%, 94 \%$, and $98 \%$. The value of the infiltration capacity is inversely proportional to the value of the saturation degree, where the greater the value of the soil infiltration capacity, the lower the degree of soil saturation.

Based on the analysis of daily infiltration capacity, the infiltration rate and cumulative infiltration in study locations decrease as the value of the soil saturation degree increases.

The results of the analysis of infiltration capacity for normal, heavy, and very heavy rain models can be seen in Tables V-VII.

TABLE III

THE DOMINANT RAIN DURATION FROM RAINROSE ANALYSIS

\begin{tabular}{ccccc}
\hline \hline No. & Location & $\begin{array}{c}\text { Normal } \\
\text { Rainfall } \\
t(\text { day) }\end{array}$ & $\begin{array}{c}\text { Heavy Rainfall } \\
\text { (day) }\end{array}$ & $\begin{array}{c}\text { Very Heavy } \\
\text { Rainfall } \\
t \text { (day) }\end{array}$ \\
\hline 1 & Sukasada & 13 & 6 & 5 \\
2 & Sawan & 9 & 7 & 6 \\
\hline \hline
\end{tabular}

TABLE IV

RECAPITULATION OF INTENSITY REPRESENTING NORMAL, HEAVY, AND VERY HEAVy RAINFALl ThAT OCCURRED At THE STUDy Site

\begin{tabular}{ccccc}
\hline \hline \multirow{2}{*}{ No. Location } & $\begin{array}{c}\text { Normal Rainfall } \\
i(\mathrm{~mm} / \text { day })\end{array}$ & $\begin{array}{c}\text { Heavy Rainfall } \\
i(\mathrm{~mm} / \text { day })\end{array}$ & $\begin{array}{c}\text { Very Heavy Rainfall } \\
i(\mathrm{~mm} / \text { day })\end{array}$ \\
\hline 1 & Sukasada & 49.1 & 87.33 & 155.38 \\
2 & Sawan & 48.24 & 92.27 & 210.11 \\
\hline
\end{tabular}

TABLE V

CALCULATION RESULTS OF NORMAL RAIN INFILTRATION CAPACITY Green-Ampt

\begin{tabular}{ccccc} 
Location & $\begin{array}{c}S_{r} \\
(\%)\end{array}$ & $\begin{array}{c}F \text { Cumulative } \\
\text { infiltration } \\
(\mathrm{mm})\end{array}$ & $\begin{array}{c}f \text { Infiltration rate } \\
(\mathrm{mm} / \text { day })\end{array}$ & $\begin{array}{c}t_{p} \text { Ponding time } \\
(\text { day })\end{array}$ \\
\hline \multirow{3}{*}{ Sukasada (Gitgit) } & 96 & 3.710 & 0.149 & $6.360 \times 10^{-05}$ \\
& 98 & 3.023 & 0.134 & $5.026 \times 10^{-05}$ \\
Sukasada & 93 & 2.776 & 0.122 & $4.136 \times 10^{-05}$ \\
(Pancasari) & 96 & 2.137 & 0.113 & $3.481 \times 10^{-05}$ \\
& 98 & 1.559 & 0.088 & $1.992 \times 10^{-05}$ \\
Sawan & 93 & 9.458 & 0.066 & $9.996 \times 10^{-06}$ \\
(Sekumpul) & 96 & 8.541 & 0.525 & $4.797 \times 10^{-04}$ \\
& 98 & 7.864 & 0.488 & $3.823 \times 10^{-04}$ \\
& 93 & 10.274 & 0.621 & $5.772 \times 10^{-04}$ \\
Sawan (Lemukih) & 96 & 9.460 & 0.575 & $4.813 \times 10^{-04}$ \\
& 98 & 8.871 & 0.543 & $4.174 \times 10^{-04}$ \\
\hline
\end{tabular}


TABLE VI

CALCULATION RESULTS OF HEAVY RAIN INFILTRATION CAPACITY

\begin{tabular}{ccccc}
\hline \hline & & \multicolumn{3}{c}{ Green-Ampt } \\
Location & $\begin{array}{c}S_{r} \\
(\%)\end{array}$ & $\begin{array}{c}F \text { Cumulative } \\
\text { infiltration } \\
(\mathrm{mm})\end{array}$ & $\begin{array}{c}\text { Infiltration rate } \\
(\mathrm{mm} / \text { day) }\end{array}$ & $\begin{array}{c}t_{p} \text { Ponding time } \\
(\text { day) }\end{array}$ \\
\hline \multirow{2}{*}{ Sukasada (Gitgit) } & 96 & 2.486 & 0.213 & $4.741 \times 10^{-05}$ \\
& 98 & 2.018 & 0.191 & $3.746 \times 10^{-05}$ \\
Sukasada & 93 & 1.853 & 0.174 & $3.083 \times 10^{-05}$ \\
(Pancasari) & 96 & 1.419 & 0.160 & $2.594 \times 10^{-05}$ \\
& 98 & 1.025 & 0.124 & $1.485 \times 10^{-05}$ \\
Sawan & 93 & 8.246 & 0.091 & $7.451 \times 10^{-06}$ \\
(Sekumpul) & 96 & 7.438 & 0.639 & $6.405 \times 10^{-04}$ \\
& 98 & 6.840 & 0.582 & $5.105 \times 10^{-04}$ \\
Sawan (Lemukih) & 96 & 8.968 & 0.690 & $7.238 \times 10^{-04}$ \\
& 98 & 7.250 & 0.639 & $6.426 \times 10^{-04}$ \\
\hline \hline
\end{tabular}

TABLE VII

CALCUlation Results OF VERY HEAVy RAIN INFILTRATION CAPACITY

\begin{tabular}{ccccc}
\hline \hline & \multicolumn{4}{c}{ Green-Ampt } \\
Location & $\begin{array}{c}S_{r} \\
(\%)\end{array}$ & $\begin{array}{c}F \text { Cumulative } \\
\text { infiltration } \\
(\mathrm{mm})\end{array}$ & $\begin{array}{c}\text { Infiltration rate } \\
(\mathrm{mm} / \text { day) }\end{array}$ & $t_{p}$ Ponding time \\
& & day) & 0.232 & $2.009 \times 10^{-05}$ \\
& 93 & 2.263 & 0.208 & $1.587 \times 10^{-05}$ \\
Sukasada (Gitgit) & 96 & 2.018 & 0.190 & $1.306 \times 10^{-05}$ \\
& 98 & 1.837 & 0.174 & $1,099 \times 10^{-05}$ \\
Sukasada & 93 & 1.686 & 0,135 & $6.292 \times 10^{-06}$ \\
(Pancasari) & 96 & 1.290 & 0.099 & $3.157 \times 10^{-06}$ \\
& 98 & 0.931 & 0.682 & $9.243 \times 10^{-05}$ \\
Sawan & 93 & 7.587 & 0.620 & $7.367 \times 10^{-05}$ \\
(Sekumpul) & 96 & 6.837 & 0.574 & $6.115 \times 10^{-05}$ \\
& 98 & 6.284 & 0.737 & $1.112 \times 10^{-04}$ \\
Sawan (Lemukih) & 96 & 8.255 & 0.682 & $9.274 \times 10^{-05}$ \\
& 98 & 7.590 & 0.642 & $8.043 \times 10^{-05}$ \\
\hline \hline
\end{tabular}

The infiltration calculation for heavy and very heavy rainfall also reveals that the infiltration rate and cumulative infiltration decrease along with the increasing value of the soil saturation degree. Based on the results in Tables V-VII, it can be concluded that the modified Green-Ampt equation can be used in analyzing infiltration on spatial slopes. The value of the infiltration capacity uses the Green-Ampt equation for the analysis of slope stability based on the influence of rainwater infiltration. In general, changes in infiltration rate and cumulative infiltration during rain can be explained by graphs that show the relation between infiltration and time as seen in the following. Fig. 4 shows that the infiltration is strongly influenced by ponding time where, during rain, rainwater will infiltrate the soil until reaching the ponding time. After reaching the ponding time, the infiltration value tends to decrease until the rain stops. Meanwhile, Fig. 5 shows that the cumulative infiltration value will continue to increase until the rain stops, showing that the cumulative value of rain affects the cumulative infiltration value. The greater the cumulative value of rainfall is, the greater the cumulative infiltration value is, hence, the greater the threat to the soil movement is.

\section{IV.2. Shear Strength Results}

Water infiltration causes a decrease in the value of soil shear strength parameters and it affects slope stability.

Dry soil has a suction value or negative pore water pressure that will change under wetting conditions. Pore water pressure that is initially negative will increase to zero when the soil conditions are at the level of the groundwater (g.w.l) and will become positive when the soil conditions are below the groundwater level. This change in pore water pressure has also resulted in changes in soil shear strength parameters, especially cohesion value and internal friction angles. The Ho and Fredlund equations are used to estimate the value of soil shear strength parameters based on suction values.

Changes in soil shear strength parameters for each location can be seen in Table VIII. Fig. 6 shows that there is a change in the value of soil parameters against the changes in the suction value. In general, the cohesion value $(c)$ of the soil will decrease as the suction value decreases. When the suction value is high, the soil is dry.

Hence, the soil cohesion value is higher. Meanwhile, when the suction value is low, the soil is wet, causing the soil cohesion value to decrease.

The value of the internal friction strength parameter $\left(\varphi_{b}\right)$ changes relative to the suction value. The change in $\varphi_{b}$ is inversely proportional to the change in cohesion value, in which the value of $\varphi_{b}$ will decrease as the suction value increases and the level of saturation decreases.

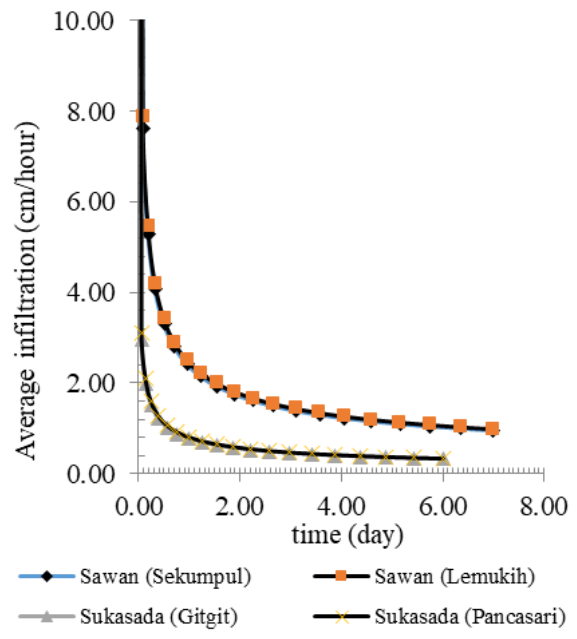

Fig. 4. Infiltration rate during rain in study locations

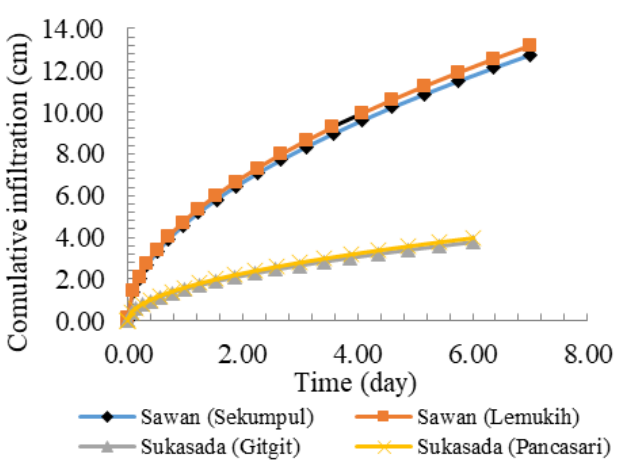

Fig. 5. Cumulative infiltration during rain in study locations 


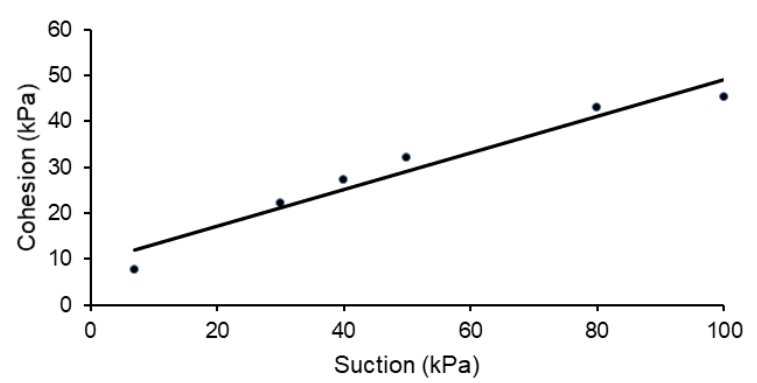

Fig. 6. A decrease in cohesion value against change of suction value

TABLE VIII

Changes In The VAlue Of SoIl SHEAR Strength PARAMETERS BASED ON SUCTION VALUES

\begin{tabular}{ccccc}
\hline \hline \multirow{2}{*}{ Research Location } & $S_{r}$ & Suction & \multicolumn{2}{c}{ Ho and Fredlund } \\
& $(\%)$ & $(\mathrm{kPa})$ & $c(\mathrm{kPa})$ & $\varphi^{b}\left({ }^{\circ}\right)$ \\
\hline & 70 & 100 & 47.053 & 23.390 \\
& 80 & 80 & 44.621 & 27.033 \\
Sawan (Sekumpul) & 90 & 50 & 33.460 & 30.677 \\
& 93 & 30 & 28.572 & 31.770 \\
& 96 & 10 & 23.180 & 32.863 \\
& 98 & 7 & 7.121 & 33.591 \\
Sawan (Lemukih) & 70 & 100 & 47.053 & 23.390 \\
& 90 & 80 & 44.620 & 27.033 \\
& 90 & 50 & 33.460 & 30.677 \\
& 96 & 40 & 28.571 & 31.770 \\
Gitgit (Gitgit) & 98 & 30 & 23.180 & 32.862 \\
& 70 & 100 & 46.803 & 23.554 \\
& 80 & 80 & 44.364 & 27.222 \\
& 90 & 50 & 33.124 & 30.891 \\
& 96 & 30 & 21.950 & 31.992 \\
& 98 & 10 & 9.727 & 33.092 \\
Gitgit (Pancasari) & 5 & 6.561 & 33.826 \\
& 93 & 100 & 48.120 & 23.668 \\
& 96 & 80 & 45.909 & 27.485 \\
& 98 & 50 & 34.693 & 31.303 \\
& 90 & 23.354 & 32.448 \\
& 90 & 10.932 & 33.593 \\
& 90 & 7.707 & 34.357 \\
\hline
\end{tabular}

Safety factor analysis is done by modeling the dominant duration of rainfall that occurs in the rainy season (6 months of the rainy season from November to April). According to the category of the slope safety factor in [22], [23], slopes fail if they meet the requirements of $1.07<\mathrm{SF}<1.25$. The results of the research show that in the heavy rain model, the value of the slope safety factor in the study area ranges from 1.00 to 1.03 . Hence, the slope in the study location is likely to fail. It happens because the intensity and the dominant duration of the rain in the study location are quite high during the rainy season.

\section{IV.3. The Mapping of Safety Factor}

The analysis continues by combining infiltration and safety factor to create a spatial-temporal prediction map of the soil movement hazard. The extrapolation results for the production of spatial-temporal map of landslide hazard in Fig. 7 are used to estimate slope stability or landslide hazard areas in Sukasada and Sawan Subdistricts in a spatial manner, assuming that the soil saturation value is at a degree of $90 \%-93 \%$, with the calculation of the safety factor (SF) due to infiltration is on infinite slopes, which result in safety factor classification of $\mathrm{SF}>2.13$ (low/stable), $1.40<\mathrm{SF}<2.12$ (medium/critical), and SF $<1.39$ (high/landslide).

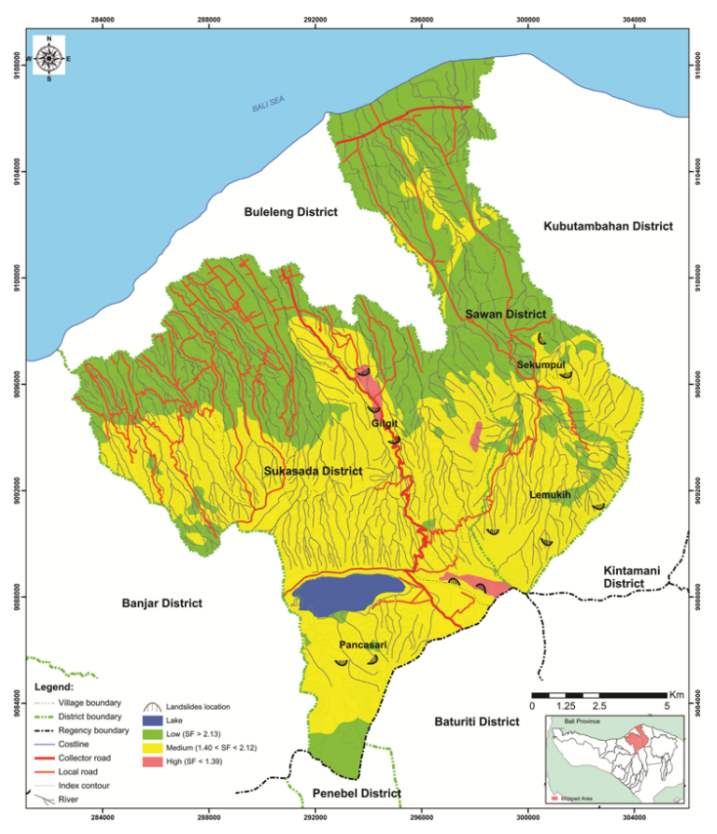

Fig. 7. A map of safety factor on heavy rain models with rainfall intensity of 87.32-92.27 mm/day and rainfall duration of 6-7 days and the safety factor is in the range of 2.131 .39 , where more than $50 \%$ of the study area has a low level of hazard and rare soil movement

\section{Conclusion}

Slope safety factor occurs due to the cumulative infiltration value. Hence, cumulative infiltration affects the value of the safety factor. The cumulative infiltration value is a combination of the previous month, so the infiltration that occurs is considered a continuation from the previous condition. The combination of the 2dimensional infinite slope stability model, infiltration model, and spatial analysis results in a spatial-temporal prediction map of slope stability at various slope based on the value of safety factor (SF). According to the safety factor analysis, the value of the safety factor is strongly influenced by rain intensity and duration. In Ward (1978), in stable areas or areas with a safety factor greater than 2 , soil movement is possible but very rare.

Therefore, the areas considered stable or have a low and very low hazard risk, as evidenced by the absence or the small amount of soil movement, are not exempt from the possibility of future slope instability. Human activities such as slope cutting and natural events such as earthquakes can trigger it. Changes in shear parameters that occur due to changes in suction are changes in the value of $\varphi b$, which is inversely proportional with changes in cohesion values, where the value of $\varphi b$ will decrease along with the increasing suction value and the decreasing level of soil saturation, while the cohesion value $(c)$ will decrease as the suction value decreases. Rain with an intensity of $87.32-92.27 \mathrm{~mm} / \mathrm{day}$ and a 
duration of 6-7 days in each study location in Sukasada and Sawan Subdistricts has a significant influence on slope stability, with the classification of $\mathrm{SF}>2.13$ (low/stable), $1.40<\mathrm{SF}<2.12$ (moderate/critical), and $\mathrm{SF}<$ 1.39 (high/landslide). Landslides that occur in each study location are surface slides because the depth of the landslide field in the location is estimated to be $<1500$ $\mathrm{mm}$. The estimation shows that slope instability and landslides occur in January, the third month of the rainy season.

\section{Acknowledgements}

The authors would like to thank the Head and the technicians of the Soil Mechanics Laboratory of Universitas Gadjah Mada, Yogyakarta, and the Soil Mechanics Laboratory of Universitas Warmadewa, Bali for their help during the experiments. Great appreciation is also given to the Ministry of Research, Technology and Higher Education of the Republic of Indonesia for financial support.

\section{References}

[1] T. F. Fathani, D. Karnawati, and W. Wilopo, Promoting a Global Standard for Community-Based Landslide Early Warning Systems (WCoE 2014-2017, IPL-158, IPL-165), Adv. Cult. Living with Landslides, vol. 5, pp. 1-557, 2017. doi: https://doi.org/10.1007/978-3-319-59469-9_30

[2] I. N. Sinarta, Level of Threat of Land Movement in Volcanic Rocks in Bali Based on Comprehensive Geotechnical Approaches, 1st ed. Yogyakarta: Desertasi, 2018.

[3] Pusdalop BPBD Provinsi Bali, Bali Province Disaster Report 2010-2014, Denpasar, 2015.

[4] I. N. Sinarta, A. Rifa'i, T. F. Fathani, and W. Wilopo, Slope Stability Assessment Using Trigger Parameters and SINMAP Methods on Tamblingan-Buyan Ancient Mountain Area in Buleleng Regency, Bali, Geosciences, vol. 7, no. 4, p. 110, 2017. doi: https://doi.org/10.3390/geosciences7040110

[5] P. M. Hadiwidjojo, H. Samodra, and T. . Amin, Geological Map of Bali, Nusa Tenggara, Bandung, 1998.

[6] T. C. Pierson, Piezometric Response To Rainstorms In Forested Hillslope Drainage Depressions, J. Hydrol. (New Zealand), vol. 19, no. 1, pp. 1-10, 1980.

[7] I. N. Sinarta, A. Rifa'i, T. F. Fathani, and W. Wilopo, Landslide Hazards Due To Rainfall Intensity in the Caldera of Mount Landslide Hazards Due To Rainfall Intensity in, 1st Warmadewa Univ. Int. Conf. Archit. Civ. Eng. Sustain. Des. Cult. 20th Oct. 2017, Fac. Eng. Warmadewa Univ. Bali LANDSLIDE, vol. 1, pp. 160-167, 2017.

[8] Mendjel, D., Bekkouche, S., Messast, S., Boukhatem, G., Analysis of Uncertainty Effect on Slopes Reliability by Genetic Algorithm Method, (2018) International Review of Civil Engineering (IRECE), 9 (6), pp. 234-240. doi: https://doi.org/10.15866/irece.v9i6.16241

[9] H.-M. Tang, X. Liu, X.-L. Hu, and D. V. Griffiths, Evaluation of landslide mechanisms characterized by high-speed mass ejection and long-run-out based on events following the Wenchuan earthquake, Eng. Geol., vol. 194, pp. 12-24, Aug. 2015. doi: https://doi.org/10.1016/J.ENGGEO.2015.01.004

[10] F. Guzzetti, A. Carrara, and R. Paola, Use of GIS Technology in the Prediction and Monitoring of Landslide Hazard, Nat. Hazards, vol. 20, no. November, pp. 117-135, 1999.

[11] Patuti, I., Rifa'i, A., Suryolelono, K., Siswosukarto, S., Model of Timber Crib Walls Using Counterweight in Bone Bolango Regency Gorontalo Province Indonesia, (2018) International Review of Civil Engineering (IRECE), 9 (3), pp. 98-104. doi: https://doi.org/10.15866/irece.v9i3.14050
[12] K. P. Acharya, N. P. Bhandary, R. K. Dahal, and R. Yatabe, Seepage and slope stability modelling of rainfall-induced slope failures in topographic hollows, Geomatics, Nat. Hazards Risk, vol. 7, no. 2, pp. 721-746, 2016. doi: https://doi.org/10.1080/19475705.2014.954150

[13] GEO-SLOPE International, Seepage Modeling with SEEP/W 2007, Geostudio Help., no. February, p. 307, 2010.

[14] D. Karnawati, The Natural Disasters of the Land Mass Movement in Indonesia and its Mitigation Efforts, Yogyakarta: Departemen Teknik Geologi Fakultas Teknik Universitas Gadjah Mada, 2005.

[15] S. Sosrodarsono and K. Takeda, Hydrology for Irrigation. Jakarta: PT. Pradnya Paramita, 2003.

[16] V. Te Chow, D. R. Maidment, and L. W. Mays, Applied Hydrology. New York: McGraw-Hill, Inc., 1987.

[17] L. W. Abramson, T. S. Lee, S. Sharma, and G. M. Boyce, Slope Stability and Stabilization Methods, 2nd ed. New York: John Wiley \& Sons, Inc., 2002.

[18] A. Rifa'i, Effect of matric suction changes on unsaturated soil parameter slope stability analiysis due to rainfall, Semin. Nasional-1-BMTTSSI-Konteks 5, pp. G15-G23, 2011.

[19] S. H. Soenarmo, I. A. Sadisun, and E. Saptohartono, Preliminary Study of the Effect of Rainfall Intensity on Estimating Spatial Based Landslide Potentials in Bandung Regency, West Java, $J$. Geoaplika, vol. 3, pp. 133-142, 2008.

[20] L. Chen and M. H. Young, Green-Ampt infiltration model for sloping surfaces, Water Resour. Res., vol. 42, no. 7, pp. 1-9, 2006. doi: https://doi.org 10.1029/2005WR004468

[21] D. G. Fredlund and H. Rahardjo, Soil Mechanics for Unsaturated Soils, John Wiley Sons, Inc., vol. 30, no. 2, pp. 113-123, 1993.

[22] J. Bowles, Physical and Geotechnical Properties Of Soil, 2nd ed. Chicago: McGraw-Hill Company, 1984.

[23] R. C. Ward, Floods: A geographical perspective, 1st ed. Macmillan, ISBN 10: 0333148924 / ISBN 13: 9780333148921 , 1978.

\section{Authors' information}

${ }^{1}$ Department of Civil Engineering, Faculty of Engineering and Planning, Warmadewa University, Indonesia.

${ }^{2}$ Department of Civil and Environmental Engineering, Faculty of Engineering, Universitas Gadjah Mada, Indonesia.

${ }^{3}$ Department of Geological Engineering, Faculty of Engineering, Universitas Gadjah Mada, Indonesia.

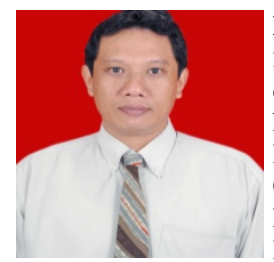

I. Nengah Sinarta was born in Denpasar, July 2, 1970. In 1996, he received a Bachelor's degree Engineering in Udayana University. Then he received a Master's degree in 2003 and a Doctoral degree in 2018 at the Department of Civil and Environmental Engineering, Faculty of Engineering, Universitas Gadjah Mada, Indonesia. In 1998, he joined Warmadewa University. His experiences include research, designing, and education. $\mathrm{He}$ also published many papers in National Conferences and National/International Journal, which focus on the field of Civil Engineering, Geotechnical Engineering, landslide hazards, and geological disaster. Mr I Nengah Sinarta joined Indonesia Society for Geotechnical Engineering (ISGE/HATTI)-ID. No.: 15.2223.OR.

E-mail: inengahsinarta@gmail.com

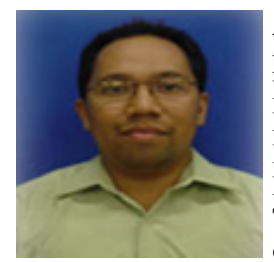

Ahmad Rifa'i was born on July 12, 1969. He pursued civil engineering education at the Faculty of Engineering in Universitas Gadjah Mada, Indonesia in 1998 and received a Bachelor's degree in 1993. He attended the Master's program at Geotechnics in Institut Teknologi Bandung, Indonesia in 1994 and obtained a Master's degree in 1996. Then in 2002, he received a Doctoral degree at The Swiss Federal Institute of Technology of Lausanne (EPFL), Switzerland. His research interest 
includes soil mechanics, tunneling, and foundation, which resulted in several publications in international journals. Dr. Ahmad Rifa'i is also a member of the Indonesia Society for Geotechnical Engineering (HATTI) and ISSMG (International Society for Soil Mechanics and Geotechnical Engineering).

E-mail: ahmad.rifai@ugm.ac.id

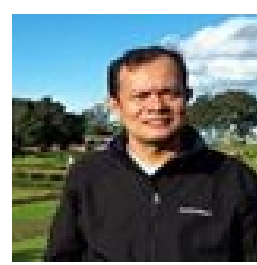

Teuku Faisal Fathani received his Ph.D from Tokyo University of Agriculture and Technology of Japan in 2005 and then continued his post-doctoral research at Ehime University in 2010 and the University of Iowa 2013-2014. He is currently a professor in Civil and Environmental Engineering, Universitas Gadjah Mada Yogyakarta (UGM). He has five patents related to multi-modal sediment disaster warning devices and becomes a prominent name in research in this area. He serves as the Director of Center for Disaster Mitigation and Technological Innovation (GamaInaTEK) UGM; Vice President of International Consortium on GeoDisaster Reduction (ICGdR); Co-Director of StIRRRD (Strengthening Indonesian Resilience: Reducing Risk from Disasters), and Director of Master Program in Disaster Management (MMB), Graduate School UGM. He is also a member of International Consortium on Landslides (ICL), Multi-modal Sediment Disaster Network (MSD-Network) and Indonesian Society for Geotechnical Engineer (ISGE).

E-mail: tfathani@ugm.ac.id

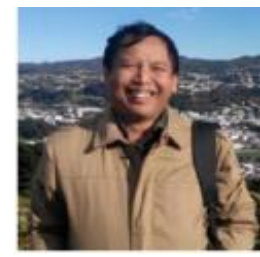

Wahyu Wilopo was born on November 19 , 1975. He obtained a Bachelor's degree at the Faculty of Geological Engineering in Universitas Gadjah Mada (1999). He earned a Master's degree at the Faculty of Mining Engineering, Chulalongkorn University, Thailand in 2004. Then he attends a Doctoral program at Kyushu University. His research interest includes geological engineering, especially concerning hydrogeology, environmental geology, disaster risk reduction, early warning system, and landslide. He has also produced several publications in the form of international journals. He is serving as the Head of the central laboratory, Universitas Gadjah Mada, Department of Geological Engineering, Hydrogeology and Disaster management.

E-mail: wilopo_w@ugm.ac.id 